\title{
CORRELATION OF NEUROETHICS AND BIOETHICS
}

\author{
Bryzgalina EV $\bowtie$, Gumarova AN
}

Lomonosov Moscow State University.

\begin{abstract}
Neuroethics is an interdisciplinary field of study that considers ethical issues raised by increased understanding of how the brain works and development of technologies of research and influence the brain function. In addition, neuroethics is understood as the study of neural processes of moral decision-making. Originally, the problems of neuroethics have developed in bioethical context. With the expansion of the set of questions and the emergence of a separate discussion of the ethics of neuroscience, as well as the development of research on classical issues of ethics using neuroimaging technologies, neuroethics is becoming a separate field of study. In the article, the authors consider two approaches to the relationship between neuroethics and bioethics: (1) neuroethics as a special area of bioethics and (2) neuroethics as an independent discipline that has its specific features. Understanding neuroethics as a part of bioethics predetermines the consideration of its problems as a study of the social consequences of the achievements of neurosciences and the normative regulation of medical and research practice. The approaches that define neuroethics as an independent field emphasize the combination of multidirectional study (ethics of neuroscience and neuroscience of ethics) as a specific feature of the discipline. These studies are related by their common object of research - the brain. The approach of reductionism underlying the dominant research in neuroethics is noted in the article as a factor of a shift of neuroethics from the humanitarian context of bioethics towards neuroscience.
\end{abstract}

Key words: Neuroethics, Bioethics, Neuroscience, Cognitive Sciences, Medical Ethics, Neurotechnologies, Social and Humanitarian Expertise

Funding. This research has been supported by the Interdisciplinary Scientific and Educational School of Moscow University «Brain, Cognitive Systems, Artificial Intelligence».

$\square$ Correspondence should be addressed: Elena V. Bryzgalina

Lomonosovsky prospekt, 27, b.4, GSP-1, Moscow, 119991, Russia; evbrz@yandex.ru

Received: 21.05.2021 Accepted: 28.05.2021 Published online: 30.06.2021

DOI: $10.24075 /$ medet.2021.013

\section{СООТНОШЕНИЕ НЕЙРОЭТИКИ И БИОЭТИКИ}

\section{Е. В. Брызгалина $\bowtie$, А. Н. Гумарова}

Московский государственный университет им. М. В. Ломоносова, Москва, Россия

\begin{abstract}
Нейроэтика является междисциплинарной областью исследования, которая рассматривает этические вопросы, связанные с углублением понимания того, как работает мозг и развитием технологий для исследования мозга и влияния на него. Кроме этого под нейроэтикой понимается исследование нейронных процессов принятия морального решения. Исторически проблематика нейроэтики развивалась в биоэтическом контексте. С расширением набора вопросов и складыванием обособленного обсуждения этики нейронаук, а также развитием исследований классических вопросов этики с применением технологий нейровизуализации, нейроэтика становится отдельной исследовательской областью. В статье авторы рассматривают два подхода к соотношению нейроэтики и биоэтики: (1) нейроэтика как специальное направление биоэтики и (2) нейроэтика как самостоятельная дисциплина, связанная с биоэтикой, но обладающая собственной предметной спецификой. Понимание нейроэтики как части биоэтики предопределяет рассмотрение её проблематики как исследования социальных последствий достижений нейронаук и нормативного регулирования медицинской и исследовательской практики. Подходы, определяющие нейроэтику как независимую область исследования, подчёркивают в качестве специфической особенности дисциплины объединение разнонаправленных исследований (этики нейронауки и нейронауки этики), связанных спецификой объекта исследований - мозга. Редукционистский подход, лежащий в основании господствующих в нейроэтике исследований, отмечен в статье в качестве фактора, отдаляющего нейроэтику от гуманистического контекста биоэтики.
\end{abstract}

Ключевые слова: нейроэтика, биоэтика, нейронауки, когнитивные науки, медицинская этика, нейротехнологии, социально-гуманитарная экспертиза

Финансирование. Исследование выполнено при поддержке Междисциплинарной научно-образовательной школы Московского университета «Мозг, когнитивные системы, искусственный интеллект».

$\varangle$ Для корреспонденции: Брызгалина Елена Владимировна

Ломоносовский проспект, д.27, корп. 4, ГСП-1, г. Москва, 119991, Россия; evbrz@yandex.ru

Поступила: 21.05.2021 Статья принята к печати: 28.05.2021 Опубликована онлайн: 30.06.2021

DOI: $10.24075 /$ medet.2021.013

\section{INTRODUCTION}

Neuroethics is a young field of study, the conceptual foundations and disciplinary boundaries of which have been determining since the early 2000s. Researchers are still discussing various approaches to understanding the issues of neuroethics, grounds for referring neuroethics to humanitarian or scientific approaches and interdisciplinary classification of questions. Unclear position of neuroethics among novel interdisciplinary areas of concern is also confirmed by various opinions about the correlation of bioethics and neuroethics. Is neuroethics a subdivision of bioethics or should it be developed independently?

It has to be noted that neuroethics is a general term for two different subjects [1]. The first subject is the ethics of neuroscience; it includes ethics in medical research, and social and humanitarian analysis of ethical and legal implications of practices associated with the use of neurotechnologies in different areas of life. The second subject is the neuroscience of ethics, which investigates the neural basis of ethical decisions as well as reconsidering the essence of ethics itself based on empirical data and brain function. There is a close 
correlation between the two subjects: neuroscience of ethics provides neuroethics with empirical materials, whereas ethics of neuroscience provides for regulatory research control.

If neuroethics is considered as the ethics of neuroscience, then bioethics and neuroethics must be taken as cognate disciplines with intercrossing problematic fields. For example, the problem of death criteria is one of fundamental issues traditionally developed in bioethics. However, it is currently at the intersection of neuroethics and bioethics as the concept of brain death and criterion of death in the form of brain death are approved [2]. Modern researches of dying processes concentrate on the investigation of attenuated brain activity [3]. Though the criterion of brain death is accepted in medical practice, the validity of using the criterion is still discussed due to medical, philosophical and ethical aspects of uncertain brain death registration in practice and difficult registration of pediatric brain death.

Another common object of interest for bioethics and neuroethics is a possibility to improve a human being. Human enhancement practice is a set of biotechnology-based bodily, genetic, psychoemotional and cognitive transformations necessary to change the physical, cognitive or ethical human attributes [4].

Due to specific issues associated with free will, nature of consciousness, mechanisms of taking an ethical decision and specifics of cognitive processes, neuroethics can be considered as an autonomous research area. To solve specific problems, neuroethics uses the concepts of consciousness philosophy, cognitive neurobiology, neurobiology of emotions and social neurosciences $[5,6]$.

In this article, we consider two approaches to how to define the relationship between neuroethics and bioethics: neuroethics as subspecialty within the study of bioethics and neuroethics as an independent discipline.

\section{NEUROETHICS AS SUBSPECIALTY WITHIN THE STUDY OF BIOETHICS}

According to the first approach, neuroethics is considered as subspecialty within the study of bioethics used for ethical analysis of brain working practices but being an interdisciplinary field. The purpose of bioethics and neuroethics as its domain consists in regulatory control of practices of interacting with the living material. Being a type of applied ethics similar to bioethics, neuroethics is based on bioethical principles. One of them is the concept of Beauchamp and Childress with four principles developed: respect for autonomy, nonmaleficence, beneficence, and justice [7]. Neuroethics is comprehended as a restricted professional medical ethics, applied research ethics, social and humanitarian innovation expertise.

Neuroethical issues and its institutionalization initially occurred in the area of bioethics, and medical ethics of neurology and neurobiology, in particular. According to Illes and Bird, modern neuroethics is rooted in researches devoted to ethical implications of lobotomies, and eugenics programs in Nazi Germany, closely connected with discrimination by mental signs [8]. Since 1960-1980, brain-related ethical issues expanded as neurosciences developed and were discussed in the general context of bioethics. In 1996, the International Bioethics Committee of UNESCO (IBC) presented a special report on ethical implications of neurobiology achievements [9].

During the first conference devoted to neuroethics entitled 'Neuroethics: Mapping the Field' and held in 2002, William Safir said that the problems of bioethics and neuroethics were identical. He referred to neuroethics as 'old wine in a new bottle' [10]. Wolpe, an American bioethicist, stressed that the problem of neuroethics estimates the ethnicity of brain examination medical techniques associating neuroethics with medical ethics. He stated that 'the term neuroethics is used by European neurologists to refer to ethical issues in brain disorders, such as stroke or epilepsy, and it had been used at times of ethical concerns in psychiatry, child development, and brain injury rehabilitation' [11].

Russian neurosurgeon L. B. Likhterman speaks about medical specifics of neuroethics: 'Neuroethics aims at the development and usage of ethical standards in neurology, neurosurgery and psychiatry' [12]. According to him, neuroethics is an instrument that humanizes neurosurgery, making the tasks of neuroethics closer to biomedical ethics.

Discussing future purposes and perspectives of neuroethics, researcher Eric Rasin also believes that neuroethics is part of bioethics. The leading directions include an improved interaction between medical staff and patients during treatment, consideration of private problems associated with neurological and mental diseases such as mental patient care, investigating the phenomenon of a mental disturbance, provision of compulsory aid to patients with disturbed consciousness [13]. The important area often falls outside medical bioethics and can be taken under the responsibility of neuroethics. Thus, neuroethics, treated as humanitarian expertise of research practices and techniques, brain therapy and effect, approaches the applied bioethics.

\section{NEUROETHICS AS AN INDEPENDENT AREA OF EXAMINATION}

According to the second approach, neuroethics is an independent discipline with its own grounds and problematic boundaries, which are different from those of bioethics. The approach expands the comprehension of bioethics and includes research of the nature of ethics, effect of neurobiological research on human self-understanding and fundamental categories of law and ethics, apart from professional ethics, research ethics and humanitarian expertise [2]. As ethics of neurobiology develops, neuroethics is interpreted as a novel, reconsidered ethics of cognitively improved digital society.

The basic peculiarity of the neuroethics comprehended in such a way is that it discusses ethical issues associated with the unique organ with the functions incompatible with any other organ of a human body. It makes the related problems completely different. Based on the documents of The Human BRAIN Project (USA), it is stated that though ethical issues typical of other areas of biomedicine influence the neuroscience research, there exist special ethical aspects unique for the brain research: 'as the brain is the source of consciousness, our most inner thought and basic human needs, technological brain studies influenced the occurrence of new social and ethical issues. Can brain development research be used to improve the cognitive development at schools? What are the circumstances when mechanistic understanding of dependance and other neuropsychiatric disorders can be used to determine the liability in the legal system?' [14].

The project where neuroethics is considered as a discipline is based on the assumption that the brain is an organ, which determines the human personality and is of a paramount importance in interpersonal relations. The approach due to which neuroethics turns into an independent research area makes it closer to the biological direction of the human entity research. In the reductive approach, the thought is expressed as 'you are your brain' and 'brain is a place where the human personality is located'. Neuroethics considered as the birth of 
scientific neurorotation tends to examine not just physical but mental issues as well. Considering the disciplinary specifics of neuroethics, Vidal and Ortega state as follows: 'unlike bioethics, neuroethics could gain acceptance as it claims to be exclusive because ontological beliefs are considered as empirical facts' [15]. The reductive grounds for neuroethics are explained by the fact that neuroethics was developed due to expanding possibilities of neurovisualization. The methods of neural process visualization show what direct knowledge looks like: we are more certain that observing the physical processes that take place in the brain makes is possible to comprehend the nature of consciousness, predict human intentions and even read thoughts.

Different approaches to the philosophy of consciousness differently treat the issue of consciousness and cerebral substance correlation: some believe that mental processes result from physical processes (Churchland, Dennet), others only notice the correlation between physical and mental processes (Chalmers, Daniel) [16-19]. However, as far as an empirical aspect of neuropsychology goes, brain damage definitely leads to the change in the personal qualities and type of cognitive processes. Ethical regulation of therapeutic and research intervention to the brain, use of neuroscience potential in various fields of life, and neurobiological research of the interrelation between the brain activity and human behavior turn to be relevant general areas of neuroethics.

Russian bioethicist Sidorova suggests that based on the relationship between neuroethics and reductionism related interpretation of psychophysical processes and human nature in general, neuroethics must be considered as part of bioethics or area close to neurobiology [20]. If biological reductionism is behind the neuroethical consideration resulting from neurophysiological determination of neuroscience, neuroethics is taken as an independent discipline.

With such an approach, neuroethics cancels the focus of research and practices on the most important bioethical principles and justifies radical technological interventions into a human organism required to improve its cognitive capacity. The principle of autonomy is at risk; the human integrity is not valued anymore and becomes even more vulnerable. The subject of neuroethical discussion can be not an unacceptability of interference into an individual autonomy, but a measure where the autonomy can be disturbed. If neuroethics is taken as a philosophical project with humanitarian orientation of ethical estimation of neuroscience and neurotechnologies, the author suggests it should be considered as part of bioethics.

The second approach accepts synthesis of various ideas of a human entity to search for perspectives and limitations of the most novel technologies.

\section{CONCLUSION}

A problematic field and status of neuroethics can currently be comprehended in different ways. Every comprehension enables various matching of neuroethics and bioethics as a developed research area (the article fails to consider the aspect of institutional designing of social and humanitarian expertise in the area of bioethics and/or neuroethics).

Neuroethics is developed within the projects accompanying the largest global brain research. From the functional point of view, it is closer to bioethics, as neuroethics analyzes ethical and legal implications, limitations and regulatory control of innovations, which result from discovery of neurosciences. Neuroethics becomes alienated from a human bioethical research, as it becomes positivistic, reducing comprehension of a human to description of physical processes in the body.

The relevance of analyzing the effects of novel data about the brain and neurotechnologies on a human being and society is undoubtful. It is impossible to develop criteria estimating safety and ethics of modern practices without a valuable and holistic approach to a human being. It makes neuroethics and bioethics related as problematic fields of philosophical discourse of modernity.

\section{References}

1. Roskies A. Neuroethics for the new millennium. Neuron. 2002 35(1): 21-23.

2. Müller S, Bittlinger M, Brukamp K, Christen M, Friedrich O, Gruber M-C Jox RJ. Neuroethik — Geschichte, Definition und Gegenstandsbereich eines neuen Wissenschaftsgebiets. [Neuroethics - History, definition, and scope of a new field of science]. Ethik in Der Medizin [Ethics in Medicine] 2018; 30(2): 91-106. Germany.

3. Norton L, Gibson R, Gofton T, Benson C, Dhanani S, Shemie S Young G. Electroencephalographic Recordings During Withdrawal of Life-Sustaining Therapy Until 30 Minutes After Declaration of Death. Canadian Journal of Neurological Sciences. 2017; 44(2): 139-145.

4. Grebenshchikova EG. Biotekhnonauka i granitsy uluchsheniya cheloveka. [Biotechnoscience and boundaries of human enhancement]. Epistemologiya i filosofiya nauki [Epistemology \& Philosophy of Science] 2016; 2 (48): 34-39. Russian.

5. Farah MJ. Neuroethics: The ethical, legal, and societal impact of neuroscience. Annual Review of Psychology. 2012; 63: 571-591.

6. Glannon W. Neuroethics. Bioethics. 2006; 20(1): 37-52.

7. Beauchamp TL, Childress JF. Principles of Biomedical Ethics 1st ed. New York: Oxford University Press. 1978; 314 p.

8. Illes J, Bird SJ. Neuroethics: A modern context for ethics in neuroscience. Trends in Neuroscience. 2006; 29(9): 511-517.

9. Parsons TD. Ethical Challenges in Digital Psychology and Cyberpsychology. Cambridge University Press. Kindle Edition. 2020; 334 p

10. Saffire W. Visions for a new field of "neuroethics". In: Marcus SJ (Hrsg) Neuroethics: mapping the field. Conference proceedings. Dana Foundation, San Francisco. 13-14. May 2002; 5 s.

11. Wolpe P. R. Neuroethics. In Stephen G. (ed.). Encyclopedia of bioethics. N. Y.: Macmillan. 2004; 1894-1898

12. Likhterman LB, Likhterman BL. Etika i faktory gumanizatsil sovremennoi neirokhirurgii. [Ethics and factors of humanization of modern neurosurgery]. Istoriya meditsiny [History of Medicine] 2015; 2(3): 416-425. Russian.

13. Racine E. Pragmatic Neuroethics: Improving Treatment and Understanding of the Mind-Brain. Cambridge, Mass.: MIT Press. 2010; $290 \mathrm{p}$

14. Brain Research through Advancing Innovative Neurotechnologies (BRAIN) Working Group Report to the Advisory Committee to the Director, NIH. 2014. Available at: https://braininitiative. nih.gov/strategic-planning/brain-2025-report Accessed: 16.03.2021.

15. Vidal F, Ortega F. Being brains. Making the cerebral subject. Fordham University Press, New York. 2017. 328 p.

16. Churchland P. S. Neurophilosophy: Toward A Unified Science of the Mind-Brain. MIT Press. 1989; 560 p.

17. Dennett D, Allen L. (ed.) Consciousness Explained. The Penguin Press. 1991; $511 \mathrm{p}$.

18. Chalmers D. The Conscious Mind: In Search of a Fundamenta Theory. New York: Oxford University Press. 1996; 432 p.

19. Gabriel' M. Ya ne est' mozg: Filosofiya dukha dlya XXI veka. [I am Not a Brain: Philosophy of Mind for the 21st Century] M.: URSS: LENAND. 2020. Russian.

20. Sidorova T. A. Neiroetika mezhdu etikoi i moral'yu. [Neuroethics: between ethics and morality] Idei i idealy [Ideas \& Ideals] 2018; 36(2): 75-99. Russian. 


\section{Литература}

1. Roskies A. Neuroethics for the new millennium. Neuron. 2002; 35(1): 21-23.

2. Müller $S$, Bittlinger $M$, Brukamp $K$, Christen $M$, Friedrich $O$, Gruber M-C, Jox RJ. Neuroethik - Geschichte, Definition und Gegenstandsbereich eines neuen Wissenschaftsgebiets. Ethik in Der Medizin. 2018; 30(2): 91-106.

3. Norton L, Gibson R, Gofton T, Benson C, Dhanani S, Shemie S, Young G. Electroencephalographic Recordings During Withdrawal of Life-Sustaining Therapy Until 30 Minutes After Declaration of Death. Canadian Journal of Neurological Sciences. 2017; 44(2): 139-145.

4. Гребенщикова Е. Г. Биотехнонаука и границы улучшения человека. Эпистемология и силососрия науки. 2016; 2 (48): 34-39.

5. Farah MJ. Neuroethics: The ethical, legal, and societal impact of neuroscience. Annual Review of Psychology. 2012; 63: 571-591.

6. Glannon W. Neuroethics. Bioethics. 2006; 20(1): 37-52.

7. Beauchamp TL, Childress JF. Principles of Biomedical Ethics 1st ed. New York: Oxford University Press. 1978; 314 p.

8. Illes J, Bird SJ. Neuroethics: A modern context for ethics in neuroscience. Trends in Neuroscience. 2006; 29(9): 511-517.

9. Parsons TD. Ethical Challenges in Digital Psychology and Cyberpsychology. Cambridge University Press. Kindle Edition. 2020; 334 p.

10. Saffire W. Visions for a new field of "neuroethics". In: Marcus SJ (Hrsg) Neuroethics: mapping the field. Conference proceedings. Dana Foundation, San Francisco. 13-14. May 2002; 5 s.
11. Wolpe PR. Neuroethics. In Stephen G. (ed.). Encyclopedia of bioethics. N. Y.: Macmillan. 2004; 1894-1898

12. Лихтерман Л. Б., Лихтерман Б. Л. Этика и факторы гуманизации современной нейрохирургии. История медицины. 2015; Т. 2. № 3: 416-425.

13. Racine E. Pragmatic Neuroethics: Improving Treatment and Understanding of the Mind-Brain. Cambridge, Mass.: MIT Press. 2010; 290 p.

14. Brain Research through Advancing Innovative Neurotechnologies (BRAIN) Working Group Report to the Advisory Committee to the Director, NIH. 2014. Available at: https://braininitiative. nih.gov/strategic-planning/brain-2025-report Accessed: 16.03.2021.

15. Vidal F, Ortega F. Being brains. Making the cerebral subject. Fordham University Press, New York. 2017; 328 p.

16. Churchland PS. Neurophilosophy: Toward A Unified Science of the Mind-Brain. MIT Press. 1989; $560 \mathrm{p}$

17. Dennett D, Allen L. (ed.) Consciousness Explained. The Penguin Press. 1991; $511 \mathrm{p}$

18. Chalmers D. The Conscious Mind: In Search of a Fundamental Theory. New York: Oxford University Press. 1996; 432 p.

19. Габриэль М. Я не есть мозг: Философия духа для XXI века. Пер. с нем. М.: УРСС: ЛЕНАНД. 2020; 304 с.

20. Сидорова Т. А. Нейроэтика между этикой и моралью. Идеи и идеалы. 2018; 36 (2): 75-99. 